cipal researcher, the institution where the work is performed, and the MRC. The chief responsibility lies with the principal investigator.

In its report, the ad hoc committee attempted to relate its proposed standards to those of the US National Institutes of Health and the UK Working Party on the Practice of Genetic Manipulation. "Level A requires no special design features beyond those suitable for a well-designed laboratory," the report said. The level is similar to the NIH's P1, but less stringent than the UK's Category I.

Level $\mathrm{B}$ requires a ventilated cabinet and is similar to the NIH P2 and the UK Category I. Level $C$ requires a segregated room or cubicle from which all air is exhausted directly to the outside or is recirculated after passage through a high efficienoy particulate air filter. In addition, all air exhausted from protective hoods must be passed through a HEPA filter. This level is more stringent than the NIH P2, less stringent than NXH P3, and similar to UK Category II.

Level D requires a directed airflow through the entire laboratory and thence directly to the outside. All exhaust air must be filtered through a HEPA filter. This level is similar to NIH P3 but less stringent than UK Category III. Level E requires the addition of an air lock, a Type III biological safety cabinet, an emergency plan and alarm system, and a safety cabinet outside the laboratory area. It is more stringent than NIH P3 and similar to UK Category III.

Finally, Level $\mathrm{F}$ calls for an isolation unit geographically separate from other areas. This separation may be by means of a separate building or by a separate air system in a multipurpose building. It is the equivalent of NIH P4 and UK Category IV.

A number of experiments with uncharacterised or partially characterised DNA are forbidden at present:

- The deliberate creation of recombinant DNA expected to make harmful products, such as plant pathogens of increased virulence.

- The deliberate release into the national environment of an organism containing recombinant DNA.

- The use of recombinant DNA to transfer drug resistance to microorganisms not known to acquire it naturally, if such transfer could compromise the effective use of the drug in human or veterinary medicine or agriculture.

Other experiments are to be individually assessed by the MRC to determine whether they should be allowed to proceed and, if so, what containments are necessary. These include etiological agents that may pose a special hazard because of particular reasons (that is, that they do not occur in Canada); plants, animals or insects that are either poisonous or whose entry into Canada requires a special permit because of pathogenicity; and all viruses that require containment levels above $\mathbf{B}$.

The report pointed out that guidelines would require periodic review in the light of now information, and that there would still be experiments for which guidelines do not provide explicit containment requirements. For these reasons, the committee proposed that the council set up a standing committee to review the needs and advise the council.

\title{
BRITAIN
}

\section{Windscale: no escape}

No development connected with the Windscale plant operated by British Nuclear Fuels Ltd (BNFL) now escapes national headlines. Chris Sherwell outlines some of the latest problems

WINDSCALE remains in the front line of an increasingly controversial debate over nuclear power in Britain. What encouragement there was last week for BNFL came in the House of Commons, when at the end of a second reading debate on the Nuclear Industry (Finance) Bill a vote was recorded of 196 to 22 in favour. Among other things, the bill provides for an increase from $£ 75$ million to $£ 300$ million ( $£ 500$ million by order of parliament) in the limits of the capital which BNFL can raise with government backing

$\mathrm{BNFL}$ is reluctant to place any interpretation on the vote for the bill or on its content, but late last year, when expansion at Windscale came under heavy scrutiny, Mr Con Allday, BNFL's managing director, did draw encouragement from the support which he said the existing guarantees represented.

In the House last week, Mr Anthony Wedgwood Benn, the Secretary of State for Energy, implied that the bill was at least a case of prudent prepara- tion. Although he was at pains to stress that the authority provided by the bill would not become operative without planning authority for the expansion, he said it was important that the company should be able to keep open with its customers the option of undertaking reprocessing business should that authority be forthcoming.

On both these aspects there have been some further developments recently. It was just before Christmas that Mr Peter Shore, the Secretary of State for the Environment, announced that BNFL's application to build its proposed oxide fuel reprocessing plant would require the sanction of a public inquiry. $\mathrm{Mr}$ Shore also indicated that such a procedure would be unlikely in respect of applications for Magnox fuel facilities and for proposed research projects.

BNFL has since submitted a separate application for the latter expansion to Cumbria County Council, but by last week had yet to announce that it proposed to go ahead with the oxide plant application.

On the related matter of the need for BNFL to keep its options open with its customers, the possibility has now emerged that, when it makes its application, BNFL will split it in two, one asking for permission to build the reprocessing plant itself, and the other seeking permission to construct ponds in which oxide fuel might be stored pending reprocessing. Whether the latter proposal could be sanctioned without an inquiry is not clear, since no one is actually admitting that it is under active consideration. But in the House Mr Benn did manage to give a hint on the matter.

Responding to a question on the building of storage ponds, he said that it was necessary for the company to take discussions to the point of concluding provisional contracts, and that he was having discussions with BNFL "about procedures along these lines". It is thought that this might be a way for BNFL to give additional assurances to the Japanese, at the moment the most important overseas customers. A high level delegation from Japan was in Britain last week for talks with the Departments of Energy and the Environment, with BNFL and with the Cumbria County Council.

Whether the whole issue remains one for the relevant British and Japanese authorities alone, however, is another question. The United States, as supplier of nuclear fuel for stations in Japan and other countries, is in a position to exercise a veto over what happens to spent fuel earmarked for reprocessing.

BNFL are not prepared to comment on this authorisation procedure, which derives from the requirement that any transfer $\approx$ fissile material of US origin 
between two countries outside the USA needs the approval of the US Energy Research and Development Administration. US policy thus far has been to authorise the transfer of spent fuel for reprocessing, but the UK Department of Energy says it "may well be" that as part of the US review of nonproliferation policy "further consideration will be given to the conditions under which authorisation is given". According to the Times, negotiations between British and the USA on the matter have made little progress so far.

Important as this is, though, the most immediate of Windscale's problems last week appeared to be the continuing stalemate it faced in an industrial dispute which began on 25 January and which coincided awkwardly with the Japanese delegation's visit. Changing room attendants went on strike over a claim for increased allowances for working in an active area. Other workers were laid off as a result, and the strike spread, eventually affecting some 3,000 workers. After 11 days, during which reactors had been shut down and special safety procedures adopted, workers rejected a peace formula; last week no further efforts were being planned to solve the dispute, which was costing BNFL some $£ 14,000$ a day in lost revenue.

Meanwhile, worries over the health of workers at Windscale have revived. The deaths of two Windscale workers apparently suffering from cancerrelated diseases have been the subject of separate inquests; open verdicts were recorded. Difficulties over secrecy being faced by BNFL lawyers handling two other cases, involving families of Windscale workers who died of cancerrelated diseases, are thought to be partly responsible for last week's publication by the National Radiological Protection Board (NRPB) of a paper by $\mathrm{Dr}$ G. W. Dolphin, its Assistant Director (Research and Development).

The long-promised paper is substantially the one produced in September 1975 comparing the numbers of observed and expected deaths at Windscale from various cancers. It concluded that the difference was insignificant, but was much criticised, notably by the Flowers Commission on nuclear power and the environment, particularly in being limited only to those actually employed at Windscale.

With the aid of an independent consultant epidemiologist, Dr Peter Smith, BNFL is now to conduct its own twoyear study of all 20,000 workers who have been employed at Windscale for any period of time in the past. Its findings will be lodged in a registry of radiation workers which the NRPB has established to produce a long-term study of those exposed to radiation. $\square$

USSR

\section{The web of 'secrecy'}

Vera Rich reports on the case of $\mathrm{Dr}$ Naum Salanskii, now facing problems in seeking to emigrate from the USSR

THE prospect that this year's Diamond Jubilee of the October Revolution might be marked by a spirit of amnesty and a relaxation of pressure on dissidents and minority groups is beginning to look less realistic. A vicious attack on Andrei Sakharov in the embassy 'hand-out' publication Soviet News, the arrest of members of the 'Helsinki monitoring group' (including physicist Yurii Orlov and science-fiction writer Mykola Rudenko), and now the peculiar case of Dr Naum Salanskii in Vil'nyus, all indicate an intensification rather than a relaxation of pressure.

Dr Salanskii, formerly a laboratory head at the Institute of Physics of the Siberian Branch of the Academy of Sciences of the USSR, applied in 1975 to emigrate to Israel and was, according to standard Soviet practice, dismissed from his post. Before leaving the institute, however, he managed to obtain a document signed by the Director of the Institute, Professor I. A. Terskov, which stated unequivocally that "all the works by N. Salanskii were published at home and abroad in journals and other non-secret publications".

Dr Salanskii was nevertheless refused permission to emigrate, and on the grounds of his "secret work". With Professor Terskov now retired, Dr Salanskii found it impossible to get the new Director, Professor Pershov, to confirm his predecessor's assessment. While awaiting permission, Salanskii, like so many refusniks, became associated with Mark Azbel's illicit seminars. At the end of December 1976, when the authorities broke up the attempt of the seminar group to hold a three-day symposium on Jewish life in the USSR, several members were held for a time by the police. In Salanskii's case the matter is being taken further.

According to official statements, Salanskii is being investigated on the charge of having "slandered Soviet policy regarding the Jewish minority". The issue of secrecy also occurred several times during interrogations. On one occasion an investigator, Bakuchornis, told him that he had written to Salanskii's old institute enquiring about the alleged secrecy of his work and had already received a reply. On another occasion he was told by an official of the Central Committee of the Lithuanian Communist Party that no such enquiry was ever made nor had a reply ever been received since 'criminal proceedings' had been started. "This seems rather strange", Salanskii commented, in a telephone conversation last week; "first they said that enquiries had been made and a reply received, and suddenly all this has disappeared".

Salanskii is still trying to discover details of the accusation, and has asked the investigator to explain the policy of the USSR towards the Jewish minority which he is alleged to have slandered. According to Salanskii, the investigator said he was not an expert in this field and must look it up in a book. "It seemed very odd to me," says Salanskii, "that he has been working on my case for seven weeks, but still is unable to explain the accusation. As I do not know the essence of the case, $I$ am in the meantime writing the history of my application for emigration [by way of a defence]. If I am taken to court, I will be handed the accusation just before the proceedings begin, so that I cannot prepare a defence."

Salanskii's case is noteworthy for several reasons. Isolated as he is in Vil'nyus, he does not have the moral support which one finds, for example, among the Moscow group of refusniks. And the issue of 'secrecy' has once again raised its bureaucratic head, but in this case it is not only the nature of Dr Salanskii's former work which is considered a secret, but apparently the charges against him too. An early decision has been promised as to whether the charges will be taken to court, dropped, or retained for further investigation-provided, of course, that the outcome of that decision is not itself considered an official secret.

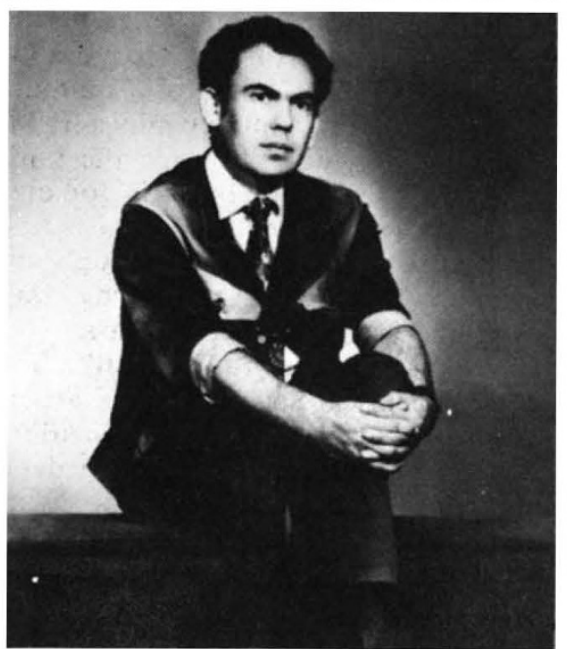

Naum Salanskii 